\title{
Celiac Crisis - An Acute Presentation of Celiac Disease in an Elderly Female Patient
}

\author{
Kundan Hanumant Khamkar1', Vikrant Dilip Kale², Sudheer Shankar Rai³, \\ Sudha Subhana Desai ${ }^{4}$, Shailesh Suryakant Kanchan ${ }^{5}$ \\ ${ }^{1,5}$ Department of General Medicine, Ruby Hall Clinic Hinjawadi, Pune, Maharashtra, India. ${ }^{2}$ Department of \\ Gastroenterology, Ruby Hall Clinic Hinjawadi, Pune, Maharashtra, India. ${ }^{3}$ Department of Emergency \\ Medicine, Ruby Hall Clinic Hinjawadi, Pune, Maharashtra, India. ${ }^{4}$ Department of General Medicine and \\ Critical Care, Ruby Hall Clinic Hinjawadi, Pune, Maharashtra, India.
}

\section{INTRODUCTION}

Celiac disease is also called as non-tropical sprue, celiac sprue, adult celiac disease and gluten sensitive enteropathy. Environmental, immunologic and genetic factors play an important role in the aetiology. ${ }^{1}$

Symptoms of celiac disease can manifest at any age throughout adulthood. Symptoms range from significant malabsorption of multiple nutrients with diarrhoea, steatorrhea, weight loss and consequences of nutrient depletion (like anaemia and metabolic bone disease).

Atypical celiac disease can present with symptoms not related to intestinal malabsorption like neurologic symptoms. Large number of patients with celiac disease can even be asymptomatic.

The gold standard in diagnosis of celiac disease is an abnormal small intestinal biopsy and the response of the condition to the elimination of gluten from the diet. Classic changes seen on duodenal /jejunal biopsy

1. An increase in number of intraepithelial lymphocytes

2. Absence or a reduced height of villi

3. A cuboidal appearance and nuclei that are no longer oriented basally in surface epithelial cells

4. Increased numbers of lymphocytes and plasma cells in lamina propria

Serology tests for celiac disease: IgA antiendomysial antibody and tissue transglutaminase TG antibodies which when positive is supportive in diagnosis. Acute presentation of celiac disease with severe metabolic derangement in adults is rare and called as "celiac crisis." 2 In crisis the patient may present with profuse diarrhoea, severe dehydration and metabolic abnormalities, hypokalaemia, hypoalbuminemia, neurologic symptoms and azotaemia. We describe one such case in an elderly female patient.
Corresponding Author: Dr. Kundan Hanumant Khamkar Ruby Hall CLinic Hinjawadi, Rajeev Gandhi Infotech Park, MIDC Phase 1, Plot No P 33 Hinjawadi, Pune - 411057, Maharashtra, India. E-mail: kundankhamkar@gmail.com

DOI: $10.14260 / j e m d s / 2022 / 56$

How to Cite This Article:

Khamkar KH, Kale VD, Rai SS, et al. Celiac crisis - an acute presentation of celiac disease in an elderly female patient. J Evolution Med Dent Sci 2022;11(01):302304, DOI: $10.14260 /$ jemds $/ 2022 / 56$

Submission 24-12-2021, Peer Review 30-12-2021, Acceptance 23-01-2022, Published 31-01-2022.

Copyright (c) 2022 Kundan Hanumant Khamkar et al. This is an open access article distributed under Creative Commons Attribution License [Attribution 4.0 International (CC BY 4.0)] 


\section{PRESENTATION OF CASE}

A 69-year-old female patient, non-diabetic, non-hypertensive, presented with complaints of loose stools for 2 months and fever for 2 days. She was evaluated clinically and investigated thoroughly. Patient had slowness of movements and slurring of speech. Routine investigations were done, which showed decreased WBC (3900), low haemoglobin (9.1, microcytic hypochromic anaemia) on CBC. Dengue NS1 antigen and rapid malaria antigen were negative. LFT showed 2 -fold rise in ALT and rise in AST. Serum potassium was found to be low (2.4 mmol/L), low calcium (7.3), low phosphate (2.1). Urine routine showed 4-6 pus cells and calcium oxalate crystals. Vitamin D and vitamin B12 came to be low i.e., 6.07 and 110.5 respectively. Lipid profile revealed raised triglycerides (182) and low HDL (9). Viral markers came to be negative.

Neurology reference was taken in view of slurring of speech and slowness of movements. A complete neurological examination was done, and she was found to have slurred speech, ataxic gait, and positive Romberg's test ${ }^{3}$ i.e., signs of sensory ataxia present. Based on the signs and low vitamin B12 levels, a provisional diagnosis of sub-acute combined degeneration of cord was made; also, possibility of metabolic encephalopathy ${ }^{4}$ and drug-induced extra-pyramidal symptoms was kept in differentials. MRI brain with cervical spine screening was done which showed age-related diffuse cerebral atrophy and small vessel ischaemic changes in periventricular white matter.

Serial potassium levels were done, which were persistently low. She was given potassium corrections. 2D echocardiography was done, which showed concentric left ventricular hypertrophy, grade II LVDD, EF $60 \%$. ESR and CRP were done which were 131 and 61 respectively. Serum LDH was 702 . Stool routine examination was done in view of low haemoglobin, and it showed mucus and occasional RBCs.

\section{INVESTIGATIONS}

\section{Haematology}

Platelet count: $150 \times 10^{3} / \mathrm{Ul}$, MPV: $9.7 \mathrm{fL}, \mathrm{MCHC}: 35.2 \mathrm{~g} / \mathrm{dL}$, RDW: 9.4\%, MCV: 126 Fl, MCH: 44.2pg, Haemoglobin: $9.1 \mathrm{G} / \mathrm{dl}$, Haematocrit: 25.9 \%, R.B.C. Count: 2.06 million/ul, Absolute Basophil Count: $0.02 \times 10^{3}$ cells/ul, Absolute Eosinophil Count: $0.14 \times 10^{3} \mathrm{cells} / \mathrm{ul}$, Absolute Monocyte Count: $0.38 \times 10^{3} \mathrm{cells} / \mathrm{ul}$, Absolute Lymphocyte Count: $1.10 \times 10^{3}$ cells/ul, Absolute Neutrophil Count: 2.27 x103cells/ul, Eosinophils: $3.5 \%$, Basophils: $0.5 \%$, Plasmodium vivax: Negative, Neutrophils: $58.1 \%$, Plasmodium falciparum: Negative, W.B.C. Count: 3900 /ul.

\section{Biochemistry}

Globulin: 3.5 gm/dL, Albumin: 3.7 g/dL, A/G Ratio: 1.0 gm/dL, Total Protein: $7.2 \mathrm{~g} / \mathrm{dL}$, Alkaline Phosphatase: $52.0 \mathrm{U} / \mathrm{L}$, Chol/HDL Ratio: 11.7, VLDL: $36.0 \mathrm{mg} / \mathrm{dL}$, LDL: $65.0 \mathrm{mg} / \mathrm{dL}$, HDL: $9.0 \mathrm{mg} / \mathrm{dL}$, Triglycerides: $182.0 \mathrm{mg} / \mathrm{dL}$, Aspartate Transaminase: $132.0 \mathrm{U} / \mathrm{L}$, Alanine Transaminase: $66.0 \mathrm{U} / \mathrm{L}$, Total Bilirubin: $1.3 \mathrm{mg} / \mathrm{dL}$, Direct Bilirubin: $0.4 \mathrm{mg} / \mathrm{dL}$, Indirect Bilirubin: $0.9 \mathrm{mg} / \mathrm{dL}$, Potassium: $2.8 \mathrm{mmol} / \mathrm{L}$, Sodium: $135.0 \mathrm{mmol} / \mathrm{L}$, Phosphorous: $2.1 \mathrm{mg} / \mathrm{dL}$, Calcium: $7.3 \mathrm{mg} / \mathrm{dL}$,
Magnesium: $1.7 \mathrm{mg} / \mathrm{dL}$, TSH: $2.76 \mathrm{ulU} / \mathrm{mL}$, Thyroxine (T4), Total: $6.37 \mathrm{ug} / \mathrm{dL}$, Tri-iodothyronine (T3): $0.539 \mathrm{ng} / \mathrm{ml}$, Urea: $19.7 \mathrm{mg} / \mathrm{dL}$, Creatinine: $0.7 \mathrm{mg} / \mathrm{dL}$, Uric Acid: $4.6 \mathrm{mg} / \mathrm{dL}$, BUN: $9.2 \mathrm{mg} / \mathrm{dL}$, Vitamin D (25-OH Vit D): $6.67 \mathrm{ng} / \mathrm{m}$, Vitamin B12: $110.5 \mathrm{pg} / \mathrm{mL}$

\section{Serology}

HBsAg: Nonreactive (0.543), Dengue NS1antigen: Negative.

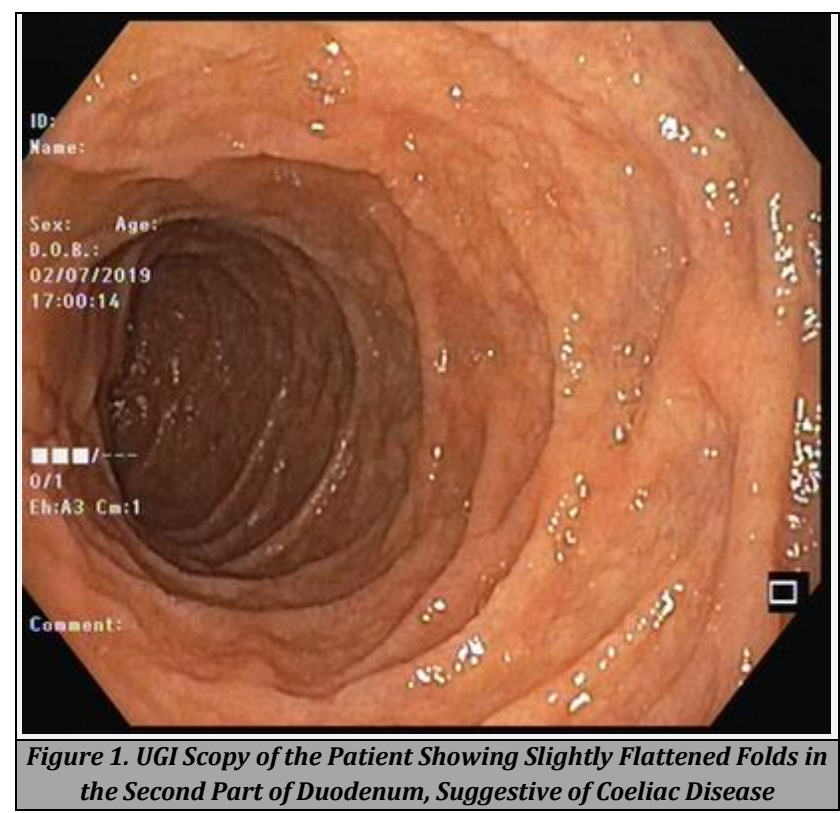

\section{DISCUSSION OF MANAGEMENT}

Patient was admitted in ICU with above mentioned complaints. All necessary investigations were done. CT brain was normal. Persistent refractory hypokalaemia, megaloblastic anaemia needed potassium, vit B12, vit D3 supplementation. Slowness in movements, ataxia was noted, suspected metabolic encephalopathy.

Nephrology reference was taken in view of persistent hypokalaemia. Urinary potassium, urine osmolality was done and it came out to be $17.66 \mathrm{mEq} / \mathrm{L}$ and $306 \mathrm{mOsm} / \mathrm{kg}$ respectively. Urine creatinine was 29.26 and urine potassiumcreatinine ratio was 60.35 . Based on the reports, tab spironolactone was added and 3 corrections of KCL were done along with MgSO4.

Gastroenterologist reference was taken in view of chronic diarrhoea and stool routine reports. Upper GI endoscopy and colonoscopy was planned and carried out after proper preparation for the same. Upper GI endoscopy showed oesophageal candidiasis, non-erosive gastropathy and slightly flat D2 folds. Colonoscopy showed multiple scattered ulcerations in terminal ileum and right side of colon.

Biopsy from second part of duodenum showed marked villous blunting, chronic inflammatory change \& prominent intraepithelial lymphocytes with focal destruction of glands consistent with celiac disease on histopathology examination.

Serum cortisol levels were sent (at 8 am and $4 \mathrm{pm}$ of the same day) which came to be normal. Blood culture revealed growth of S. typhi. 
Serial serum potassium was done from day 6 of hospitalisation till discharge. It gradually came to normal values of $4.1 \mathrm{mmol} / \mathrm{l}, 5.3 \mathrm{mmol} / \mathrm{l}$ to $5.1 \mathrm{mmol} / \mathrm{l}$ at discharge.

Haematologist reference was taken for anaemia who suggested IV iron therapy followed by oral iron and folic acid supplementation.

The patient was treated with IV antibiotics, IV fluids, symptomatic and supportive treatment. The patient clinically improved gradually with supportive treatment and gluten free diet.

On follow up of the patient after 3 weeks there was complete resolution of neurological signs, correction of anaemia and stable serum potassium and albumin levels and resolution of diarrhoea.

\section{FINAL DIAGNOSIS}

Celiac disease with celiac crisis, vitamin B 12 deficiency with metabolic encephalopathy, enteric fever and severe dimorphic anaemia.

Financial or other competing interests: None.
Disclosure forms provided by the authors are available with the full text of this article at jemds.com.

\section{REFERENCES}

[1] Jameson JL, Fauci AS, Kasper DL, et al. Harrison's principles of internal medicine. 20 th edn. Vol. 2. Chap 318. New York: McGraw-Hill Medical 2018:2251-3.

[2] Jamma S, Rubio-Tapia A, Kelly CP, et al. Celiac crisis is a rare but serious complication of celiac disease in adults. Clin Gastroenterol Hepatol 2010;8(7):587-90.

[3] Forbes J, Cronovich H. Romberg Test. In: StatPearls [Internet]. Treasure Island (FL): StatPearls Publishing 2021. Available from: https://www.ncbi.nlm.nih.gov/books/NBK563187/

[4] Butterworth RF. Metabolic encephalopathies. Chap-38. In: Siegel GJ, Agranoff BW, Albers RW, et al, eds. Basic neurochemistry: molecular, cellular and medical aspects. $6^{\text {th }}$ edn. Philadelphia: Lippincott-Raven 1999. Available from: https://www.ncbi.nlm.nih.gov/books/NBK20383/ 